\title{
Nanomolar EP4 Receptor Potency and Expression of Eicosanoid- Related Enzymes in Normal Appearing Colonic Mucosa From Patients with Colorectal Neoplasia
}

\author{
Ulrike Ries Feddersen ( $\nabla$ urf@regionsjaelland.dk ) \\ Bispebjerg Hospital \\ Sebastian Kjærgaard Hendel \\ Bispebjerg Hospital \\ Mark Alexander Berner-Hansen \\ Bispebjerg Hospital \\ Thomas Andrew Jepps \\ University of Copenhagen \\ Niels Bindslev \\ University of Copenhagen \\ Mark Berner-Hansen \\ Bispebjerg Hospital
}

\section{Research Article}

Keywords: Colorectal cancer, EP receptors, mRNA expression, short circuit current, lipoxygenase, cyclooxygenase.

Posted Date: June 9th, 2021

DOI: https://doi.org/10.21203/rs.3.rs-544138/v1

License: (c) (i) This work is licensed under a Creative Commons Attribution 4.0 International License. Read Full License 


\section{Abstract}

\section{Background}

Aberrations in cyclooxygenase and lipoxygenase (LOX) pathways in non-neoplastic, normal appearing mucosa from patients with colorectal neoplasia (CRN), could hypothetically qualify as predisposing CRNmarkers.

To test this hypothesis, biopsies were obtained during colonoscopy from macroscopically normal colonic mucosa from patients with and without CRN. Prostaglandin E2 (PGE 2$)$ receptors, EP1-4, were examined in Ussing-chambers by exposing biopsies to selective EP receptor agonists, antagonists and $\mathrm{PGE}_{2}$. Furthermore, mRNA expression of EP receptors, prostanoid synthases and LOX enzymes were evaluated using qPCR technology.

\section{Results}

Data suggest that $\mathrm{PGE}_{2}$ binds to high and low affinity EP receptors. In particular, $\mathrm{PGE}_{2}$ demonstrated EP4 receptor potency in the low nanomolar range. Similar results were detected using EP2 and EP4 agonists. In CRN patients, mRNA-levels were higher for EP1 and EP2 receptors and for enzymes prostaglandin-I synthase, 5-LOX, 12-LOX and 15-LOX.

\section{Conclusion}

In conclusion, normal appearing colonic mucosa from CRN patients demonstrates deviating expression in eicosanoid pathways, indicating a likely predisposition for early CRN development. Moreover, $\mathrm{PGE}_{2}$ potency activates high affinity EP4 receptor subtypes, supporting relevance of testing EP4 antagonists in colorectal cancer management.

\section{Background}

Colorectal cancer (CRC) is the third most common type of cancer worldwide and the second leading cause of cancer related deaths (1). CRC carcinogenesis is a multifactorial process, in which an accumulation of mutations leads to the formation of colorectal neoplasia (CRN) initially as adenomas and later adenocarcinomas (2). Genetics and chronic colonic inflammation are known risk factors for developing CRC (3) and an altered activity of the arachidonic acid (AA) metabolism including prostaglandins is likely involved. The specific mechanisms, however, are poorly understood.

Aspirin (acetylsalicylic acid) is a non-steroid anti-inflammatory drug (NSAID) and non-selective cyclooxygenase (COX) inhibitor, which ameliorates CRC development $(4,5)$. NSAIDs attenuate the inflammatory response mainly by inhibiting enzyme activity of COX isozymes, COX-1 and COX-2, which convert AA into the prostanoids $\mathrm{PGD}_{2}, \mathrm{PGE}_{2}, \mathrm{PGF}_{2 a}, \mathrm{PGI}_{2}$ and thromboxane $\mathrm{A}_{2}\left(\mathrm{TXA}_{2}\right)$, Fig. 1, (3). 
COX-2 expression is elevated in human adenomas as well as in adenocarcinomas, which is why COX-2 is believed to be central to CRN and CRC pathogenesis (6). Accordingly, the protective effect of NSAIDs on CRC development is likely due to a reduced COX-activity and associated $\mathrm{PGE}_{2}$ production $(3,5,7)$.

$\mathrm{PGE}_{2}$ elicits tumorigenic effects by binding to either of its $4 \mathrm{G}$-protein coupled surface receptors termed EP1-4, Fig. 1 (8). These effects include proliferation, migration, invasion and angiogenesis (8). Each of the receptor subtypes has been linked to CRC tumorigenesis using knock-out mice (9-11). In particular, EP4 is suspected to be of special tumorigenic importance due to its activation of several central kinases $(12,13)$.

As for the remaining prostanoids; $\mathrm{TXA}_{2}$ is considered mainly tumorigenic, $\mathrm{PGI}_{2}$ anti-tumorigenic and $\mathrm{PGF} 2$ and $P G D_{2}$ have uncertain tumorigenic roles $(14,15)$.

Recently, another AA-related pathway, the lipoxygenase (LOX) pathway, was suggested to be associated with CRC. Particularly the enzymes 5-LOX, 12-LOX and 15-LOX and its isoforms (15-LOX-1 and 15-LOX-2) appear to be involved $(16,17)$. Unlike the COX pathway, the end products of LOX enzymes are hydroxyeicosatetraenoic acids (HETEs) derivates, figure 1. Current evidence suggests a pro-tumorigenic effect of 5-LOX and 12-LOX metabolites in CRC, whereas 15-LOX-1 and 15-LOX-2 are mainly classified as anti-tumorigenic and downregulated in CRC tissue $(16,17)$. However, whether imbalances in eicosanoidrelated enzymes and receptors are initiating factors rather than consequences of neoplastic activity remains unclear.

We hypothesize that changes in eicosanoid signaling is an early tumorigenic mechanism detectable in even macroscopically normal appearing tissue. Here, we examine eicosanoid-related enzymes and receptors in non-neoplastic colonic mucosa from patients with and without CRN. Specifically, we characterize function and expression of the EP receptor subtypes and examine the expression levels of prostaglandin D2 synthase (PTGDS), prostaglandin 12 synthase (PTGIS) and the $\mathrm{PGF}_{2} \mathrm{a}$ - reductase AKR1B1 (an aldo-keto reductase), all as indicators for altered levels of their respective prostanoids (18). Finally, we determine expression levels of 5-, 12-, and 15-LOX enzymes.

\section{Methods}

\subsection{Study population}

Patients (45-80 years of age) referred for colonoscopy, were screened for participation. Exclusion criteria included history of inflammatory bowel disease, conditions of intestinal malabsorption (e.g. coeliac disease and lactose intolerance), familiar risk of CRC (hereditary nonpolyposis colorectal cancer and familial adenomatous polyposis), pregnancy and/or continuous treatment with NSAID, anti-coagulant or phosphodiesterase inhibitor. Furthermore, incomplete examination of the entire colon resulted in exclusion. 
Patients were divided into 2 groups based on endoscopic findings and medical history: patients with present or history of CRN (termed CRN patients) and patients without present nor history of CRN (termed and served as controls, CTRL patients). A total of 73 patients were enrolled. Patient group characteristics are shown in Table 1.

Table 1. Study population characteristics and medications. An expected imbalance between patient groups was observed for comorbidities and medications.

\begin{tabular}{|lll|}
\hline & CRN & CTRL \\
\hline Number & 53 & 20 \\
\hline Males / females & $27 / 26$ & $8 / 12$ \\
\hline Mean age, years (range) & $63(50-78)$ & 61 (46-76) \\
\hline Medication & 25 & 15 \\
None & 1 & 0 \\
Anti-diabetic & 2 & 0 \\
Anti-estrogen & 16 & 2 \\
Anti-hypertensive & 1 & 0 \\
Anti-epileptic & 3 & 0 \\
Asthma inhalers & 3 & 0 \\
Bisphosphonate & 1 & 0 \\
Methotrexate & 2 & 1 \\
Proton pump inhibitor & 2 & 0 \\
Selective serotonin reuptake inhibitor & 2 & 1 \\
Statins & 0 & 2 \\
Thyroid hormone & 1 & 0 \\
Triptans & 1 & 0 \\
Xanthine oxidase inhibitors & & \\
\hline
\end{tabular}

\subsection{Chemicals}

SC 51322, PF 04418948, L-798,106, L-161,982, amiloride, theophylline, indomethacin, acetazolamide, bumetanide, ouabain as well as salts for Ringer's solution were purchased from Sigma-Aldrich (Brøndby, 
Denmark). GW627368X, TCS 2510, and Sulprostone were purchased (Santa Cruz Biotechnology, Texas, USA. ONO-DI004 and ONO-AE1-259 were kindly provided by Ono Pharmaceuticals Co., Ltd. (Osaka, Japan). All other chemicals were of analytical grade.

Selection of receptor agonists and antagonists was based on a thorough search of available literature, with a preference for compounds tested on human tissue.

\subsection{Biopsy extraction}

Six endoscopic biopsies were obtained from each patient using standard biopsy forceps (Boston Scientific, Radial Jaw 4, large capacity). Biopsies were taken from macroscopically normal appearing sigmoid mucosa on retraction of the endoscope; about $30 \mathrm{~cm}$ orally from the anal verge and at least 10 $\mathrm{cm}$ from macroscopically abnormal appearing tissue.

Four biopsies allocated for functional studies, were immediately placed in an iced bicarbonate Ringer solution containing (in mM): $\mathrm{Na}^{+}(140), \mathrm{Cl}^{-}(117), \mathrm{K}^{+}(3.8), \mathrm{PO}_{4}^{-}(2.0), \mathrm{Mg}^{2+}(0.5), \mathrm{Ca}^{2+}(1.0)$, and $\mathrm{HCO}_{3}^{-}$ (25), and transferred to the laboratory. The remaining biopsies were snap frozen in liquid nitrogen and stored at $-80^{\circ} \mathrm{C}$ until further examination.

\subsection{Experimental methods}

Two experimental methods were employed: functional studies in modified air-suction Ussing (MUAS) chambers measuring short circuit current (SSC) and quantitative real-time polymerase chain reaction (qPCR).

\subsubsection{Functional studies in MUAS-chambers}

Four biopsies were mounted and oxygenated in MUAS-chambers after extraction as described by Larsen et al (19). Biopsies were bathed on both sides with $10 \mathrm{~mL}$ Ringer, supplemented with $5.5 \mathrm{mM}$ D-glucose. Temperature was maintained at $37.2^{\circ} \mathrm{C}$ by water jackets. An automated voltage-clamp device continuously recorded SCC and slope conductance (19).

Experiments began after a stable basal SCC was obtained within 10 min. All experiments were initiated by addition of amiloride ( $20 \mu \mathrm{M}$, mucosal side) to inhibit electrogenic sodium absorption mediated through epithelial sodium channels and followed by theophylline ( $400 \mu \mathrm{M}$, serosal side) to inhibit phosphodiesterase-dependent cyclic adenosine monophosphate (cAMP) degradation. Finally, to eliminate endogenous CAMP synthesis, indomethacin ( $13 \mu \mathrm{M}$, serosal side) was added and incubated for $40 \mathrm{~min}$.

Biopsies from 47 patients were treated with $\mathrm{PGE}_{2}$ and selective $\mathrm{EP}$ receptor agonists to investigate receptor function, Table 2. A single agonist was added in increasing concentrations ( $1 \mathrm{nM}$ to $5 \mu \mathrm{M}$, 
serosal side) to each MUAS-chamber. The final agonist concentration step was followed by the addition of $5 \mu \mathrm{M} \mathrm{PGE} 2$, to elicit a maximal $\mathrm{PGE}_{2}$-induced response.

Table 2. Selected agonists and antagonists and applied antagonist concentrations for functional MUAS chamber experiments.

\begin{tabular}{|lll|}
\hline Receptor subtype & Agonist & Antagonist with concentration \\
\hline EP1 receptor & ONO-DI004 & SC 51322 2 $\mu \mathrm{M}$ \\
\hline EP2 receptor & ONO-AE1-259 & PF 04418948 3 $\mu \mathrm{M}$ \\
\hline EP3 receptor & Sulprostone & L-798,106 500 nM \\
\hline EP4 receptor & TCS 2510 & L-161,982 $2 \mu \mathrm{M}$ \\
& & GW627368X 5 $\mu \mathrm{M}$ \\
\hline
\end{tabular}

Biopsies from 26 patients were treated with selective EP receptor antagonists, Table 2. A combination of 3 antagonists was added to each MUAS chamber (serosal side), to single out and investigate the remaining non-inhibited EP receptor subtype. After antagonist incubation (45 min.), cumulative doses of $\mathrm{PGE}_{2}$ were added ( $3 \mathrm{nM}$ to $1 \mu \mathrm{M}$, serosal side). The EP4 receptor was also examined with another selective antagonist, GW627368X (GW-X, $5 \mu \mathrm{M}$, serosal side).

Experiments were terminated by the addition of acetazolamide, a carbonic anhydrase inhibitor $(250 \mu \mathrm{M}$, serosal side), to measure $\mathrm{HCO}_{3}{ }^{-} / \mathrm{H}^{+}$-secretion, followed by bumetanide ( $25 \mu \mathrm{M}$, serosal side), to inhibit Na$\mathrm{K}-\mathrm{Cl}$ cotransporters and chloride secretion, and finally the $\mathrm{Na}^{+} / \mathrm{K}^{+}$-ATPase inhibitor ouabain $(0.2 \mathrm{mM}$, serosal side) to assess and ensure tissue viability and data quality.

\subsubsection{Quantitative real-time PCR}

RNA isolation

Twenty biopsies, $10 \mathrm{CRN}$ and $10 \mathrm{CTRL}$ were matched according to gender and used for further qPCR investigations. RNA was extracted from the biopsies using RNeasy Mini Kit (Qiagen, Copenhagen, Denmark). Following extraction, RNA samples were placed on ice and quantified using a Nanodrop Spectrophotometer (LabTech International) in accordance with the MIQE guidelines (20).

qPCR analysis

RNA was reverse transcribed to cDNA using the nanoScript2 (Primerdesign Ltd., U.K.) according to the manufacturer's protocol. Quantitative analysis of specific genes of interest within our cDNA samples was determined using Precision-iC SYBR green mastermix (Primerdesign Ltd.) with the CFX96 Real-Time PCR Detection System (Bio-Rad, Denmark). Duplicate reactions were performed in $20 \mu \mathrm{L}$ volumes containing $10 \mu \mathrm{L}$ Precision-iC SYBR green master mix, $300 \mathrm{nM}$ primer (Primerdesign Ltd.), $15 \mathrm{ng}$ cDNA and made up 
to $20 \mu \mathrm{L}$ with nuclease-free water. The following cycling conditions were used: initial activation at $95{ }^{\circ} \mathrm{C}$ for $10 \mathrm{~min}$., followed by 40 cycles of $95^{\circ} \mathrm{C}$ for $15 \mathrm{sec}$., and $60^{\circ} \mathrm{C}$ for $1 \mathrm{~min}$. and data was collected during each cycling phase. Melt curve analysis, to ensure each primer set amplified a single, specific product, completed the protocol. Quantification cycle $(\mathrm{Cq})$ values were determined using Bio-Rad CFX96 Manager 3.0 software and the single threshold mode.

The geNorm reference gene selection kit (Primerdesign Ltd.) was used to identify the most stable reference genes and to determine optimal number of reference genes required for reliable normalization of qPCR data in these tissue samples (21). B-actin and glyceraldehyde 3-phosphate dehydrogenase (GAPDH) were validated as the most stable reference genes in samples. The expression levels of genes of interest are expressed relative to the mean $\mathrm{Cq}$ value of the reference genes in each sample.

Primers were designed, synthesized and quality controlled by Primerdesign Ltd., Additional file 1. The sequences for the reference genes $ß$-actin and GAPDH are commercially sensitive and therefore unavailable.

\subsection{Data analyses}

The present study is exploratory and therefore not statistically powered for specific endpoints. If identical experiments were performed on several biopsies from the same patient, a mean value of parameter results was used. A comparison of parameter values between patient groups was performed by an unpaired t-test when standard deviations were equal, and a Welch's t-test if unequal. Data are presented as mean $\pm \mathrm{SEM}$.

To assess agonists and receptors, data obtained from dose-response curves were analyzed with either a single-Michaelis-Menten model (srm) or a two-Michaelis-Menten receptor/site model (trm) using Sigmaplot 13.0 for Windows, Systat Software Inc. (USA/Canada). Outcome data were maximum SCC responses $\left(R_{\text {Max }}\right)$ and $E C_{50}$ of these analyses.

All other statistics were performed using RStudio (Boston, USA), or GraphPad Prism (San Diego, USA) version 8 for the qPCR analysis. P-values $<0.05$ were considered significant.

\section{Results}

\subsection{High and low affinity EP receptors and nanomolar EP4 receptor potency}

$\mathrm{PGE}_{2}$ stimulation increased SCC in both patient groups, even at concentrations as low as $1 \mathrm{nM}$, Fig. 2. The EP4 agonist produced a similar sensitivity, demonstrating high potency in the low nanomolar range, Fig. 2. Concentrations of $30 \mathrm{nM}$ or higher were necessary to induce SCC increases when stimulating with 
the other selective EP-agonists, data not shown. Moreover, 4 out of 22 biopsies exposed to the selective EP1 agonist showed no increase in SCC.

When applying Michaelis-Menten models (srm and trm) to data, a trm provided a better fit than the srm in most analyses of data from experiments with $\mathrm{PGE}_{2}$, and agonists for EP2 and EP4 receptor subtypes, Fig. 3. Accordingly, at least 2 types of EP receptors appear activated, a high and a low affinity receptor, with different $\mathrm{EC}_{50}$ s separated by a factor up to 200 in single experiments, Fig. 3. Average separation factors of the receptors were 64 for $\mathrm{PGE}_{2}$ stimulation and 15 for the EP4 agonist, Fig. 4. In experiments using either the EP1 agonist or the EP3 agonist, trm equations did not fit convincingly. Mean $\mathrm{EC}_{50}$ values from both srm and trm analyses are summarized in Figs. 4 and 5. Using the srm, CRN patients demonstrated a higher $\mathrm{EC}_{50}$ related to stimulation with the EP4 agonist compared to CTRLs, Fig. 5.

Maximum SCC responses ( $\left.R_{\text {Max }}\right)$ computed from srm and trm are shown in Figs. 6 and 7. As PGE 2 stimulates all EP receptors, $R_{\text {Max }}$ was highest for $\mathrm{PGE}_{2}$ followed by the selective EP4 agonist eliciting approximately $50 \%$ and $75 \%$ of the $\mathrm{PGE}_{2}$ response in CTRL and CRN patients, respectively. The remaining EP-agonists had $R_{M a x}$ means ranging between $20-30 \%$ of the $P G E_{2}$ response. Finally, $R_{\text {Max }}$ was significantly increased for low affinity receptors in EP4 agonist studies (trm) in CRN patients, Fig. 7.

\subsection{Selective EP antagonists are unsuitable for determining EP receptor subtypes}

Forty-one biopsies from 26 patients were exposed to EP antagonist cocktails, intended to inhibit all but one of the $4 \mathrm{EP}$ receptor subtypes, followed by increasing $\mathrm{PGE}_{2}$ concentrations. Unexpectedly, we recorded sizable SCC increases upon $\mathrm{PGE}_{2}$ stimulation, even in the low nanomolar range, regardless of antagonist combination as well as in the presence of all $4 \mathrm{EP}$ receptor antagonists, data not shown. These data indicate a lack of irreversible and competitive inhibition by all the 4 selective EP antagonists. Thus, with the present study design and protocol, none of the employed selective antagonists qualified.

\subsection{Competitive antagonism between EP4 receptor antagonist $\mathrm{GW}-\mathrm{X}$ and $\mathrm{PGE}_{2}$}

Additional experiments were performed with only the selective EP4 antagonist GW-X, added prior to stimulation with $\mathrm{PGE}_{2}$, Table 3 . Figure 8 shows the rightward shift induced by GW-X on $\mathrm{PGE}_{2}$ doseresponse curves. The effect of $\mathrm{GW}-X$ demonstrates a competitive inhibition of $\mathrm{PGE}_{2}$ in the low nanomolar concentration range. Moreover, high $\mathrm{PGE}_{2}$ concentrations elicited about the same maximal increase in SCC regardless of GW-X addition, further supporting simple competitive antagonism between $\mathrm{GW}-\mathrm{X}$ and $\mathrm{PGE}_{2}$. An agonist-based Cheng-Prusoff analysis of the $P \mathrm{PE}_{2}-\mathrm{GW}-\mathrm{X}$ interactions resulted in an $\mathrm{IC}_{50}$ of 210 
nM for GW-X, see Additional file 2 and Table 3. To run a t-test for reliable judgement of differences in mean $\mathrm{EC}_{50} \mathrm{~s}$ for $\mathrm{GW}-\mathrm{X}$ between patient groups, more experiments are required.

Table 3. Mean $\mathrm{EC}_{50}(\mathrm{nM})$ values of $\mathrm{PGE}_{2}$ and $\mathrm{EP} 4$ agonist TCS 2510 following inhibition with GW627368X (GW-X), calculated from single receptor model (srm) equations. $N=$ number of patients, $n=$ number of biopsies.

\begin{tabular}{|lll|}
\hline & CRN $(\mathbf{N} / \mathbf{n})$ & CTRL(N / n) \\
\hline $\mathrm{PGE}_{2}$ with GW-X & $327 \pm 1.3(4 / 4)$ & $165 \pm 2(2 / 2)$ \\
\hline EP4 agonist with GW-X & $87.1 \pm 1.1(2 / 4)$ & $87.3 \pm 1.6(3 / 4)$ \\
\hline
\end{tabular}

\subsection{EP1 and EP2 receptor subtypes are upregulated in CRN patients}

mRNA expression levels of EP1 and EP2 were elevated in CRN patients compared to CTRLs, Fig. 9. EP3 and EP4 mRNA levels showed a trend of elevation in CRN patients.

\subsection{Enzymes related to the COX and LOX pathways are upregulated in CRN patients}

All investigated LOX enzymes (5-LOX, 12-LOX, and 15- LOX) demonstrated elevated levels of mRNA in CRN patients compared to CTRLs, Fig. 10. Moreover, the expression of PTGIS was significantly upregulated in the CRN group, whereas expression levels of PTGDS and ARK1B1 were unaltered, Fig.10.

\section{Discussion}

In the present study, we identified several differences in normal-appearing colonic mucosa from CRN patients, supporting the hypothesis of aberrations in enzymes and receptors of the eicosanoid pathway.

Independently of $C R N$ history, we demonstrate that $E P$ receptors bind $\mathrm{PGE}_{2}$ with 2 different affinities indicating the presence of high and low affinity EP receptor subtypes. Furthermore, we observed similar mucosal responses to selective EP2 and EP4 receptor agonists. Assuming selectivity of these compounds towards their receptors, our data suggest presence of both a high affinity EP4 and a low affinity EP2 receptor subtype $(22,23)$. High and low affinity EP receptors in human colonic mucosa have only been reported twice previously, but not investigated further $(24,25)$. 
Our experiments identified the EP4 receptor to be the EP receptor subtype with the highest secretory response in the colon, which is consistent with existing reports $(25,26)$. Furthermore, based on experiments with the highly selective EP4 receptor agonist TC 2510 (23), our data suggest a presence of both high and low affinity EP4 receptors with associated higher mean potencies and lower mean efficiencies compared to $\mathrm{PGE}_{2}$. Meanwhile, the existence of $2 \mathrm{EP} 4$ receptors was not corroborated by experiments with the selective EP4 receptor antagonist, GW-X, which was effective in human colonic mucosa previously (25). GW-X eliminated the biphasic $\mathrm{PGE}_{2}$ dose-response curve, resulting in a single receptor dose-response curve. This may be explained as a surmountable rightward potency-shift for a single EP4 high affinity receptor, moving it closer to the potency of the low affinity receptor(s) in the presence of $\mathrm{GW}-\mathrm{X}$, maintaining a combined efficiency at high concentrations of $\mathrm{PGE}_{2}$ with no antagonist present.

Stimulation of the EP4 subtype receptor is well documented as an important immunosuppressive trigger in the CRC microenvironment (27). Within the last few years, several interventional clinical phase-1 studies have been initiated with newly developed EP4 antagonists. Of these, 3 studies focus on CRC (28). Furthermore, another study points to a carcinogenic mechanism involving pericryptal COX-2-expressing fibroblasts, which exert paracrine control over tumor-initiating stem cells via a COX-2 and PGE2-EP4Yap signaling pathway $(29,30)$.

Taken together and respecting the relative few subjects in the present study, our findings support presence of a high sensitivity for $\mathrm{PGE}_{2}$ in even normal appearing colonic mucosa.

Separate additions of single selective EP antagonists did not change the ensuing PGE $_{2}$-induced SCC. Whether the $\mathrm{PGE}_{2}$-induced $\mathrm{SCC}$ increases reflect remaining secretion of incompletely inhibited EP receptor subtype(s) or resemble $\mathrm{PGE}_{2}$-induced secretion by other prostanoid receptors cannot be ascertained. Surprisingly, employed EP receptor antagonists, except for GW-X, were not useful in the present study.

Our mRNA expression studies revealed increased expressions of receptor subtypes EP1 and EP2 in CRN patients. We, as others, have investigated EP receptor expression levels in human colonic tissue previously $(31,32)$. We reported increased expression of EP3 in CRN patients, whereas expression levels of the remaining receptors were unaltered (31). Since identical primers against the subtype receptors were used in the 2 studies, the only recognized difference in study design were the number of reference genes.

Taken together, our studies indicate expressional alterations in at least 3 out of 4 EP receptor subtypes present in normal appearing colonic mucosa from CRN patients. EP4 expression levels were similar in CRN and CTRL patients. We speculate that, the previously reported elevated levels of EP4 found in human colonic adenoma and adenocarcinoma cell lines most likely reflect neoplastic time dependent differences (33).

We found PTGIS expression to be upregulated in CRN patients. Previous expression studies of $\mathrm{PTGIS} / \mathrm{PGI}_{2}$ in CRC patients have been ambiguous. One study found decreased $\mathrm{PGI}_{2}$ levels using 
radioimmunoassay in CRC patients (34). Conversely, Lichao et al. found weak or no staining of PTGIS in normal tissue (corresponding to our biopsies from CRN patients) in microarray expression studies, while PTGIS expression was detected in CRC patients and increased in CRC patients with liver metastasis (35). Merging results, we hypothesize a stepwise increase relationship in PTGIS expression and the degree of colonic mucosa dysplasia and risk for liver metastasis.

All tested LOX enzymes had higher mRNA expression levels in colonic mucosa from CRN patients. For 5LOX and 12-LOX, this is consistent with the bulk of literature. Both enzymes elicit key pro-inflammatory and pro-tumorigenic downstream functions and are upregulated in human colon adenomas and adenocarcinomas $(16,36,37)$. Our results suggest that an upregulation of the LOX pathway is already present in normal appearing colonic mucosa from CRN patients. As such, 5-LOX and/or 12-LOX, enzyme expression might possess the potential of becoming an early predictive biomarker of CRN development.

Both 15-LOX isoforms are considered anti-tumorigenic and especially 15-LOX-1 and its product 13(S)HODE appear tumor protective and downregulated in CRC tissue $(17,37)$. Our employed 15-LOX primer unfortunately did not differentiate between the 2 isoforms. In contrast to previous studies, we observed increased 15-LOX expression in the mucosa of CRN patients. Given that we only investigated normalappearing mucosa, the observed upregulated expression of 15-LOX might be a compensatory effect before mucosal cells become neoplastic. It would be interesting to further track the expression of 15-LOX, to determine whether the expression is suppressed as the cells become carcinogenic.

\section{Conclusions}

Normal appearing colonic mucosa from patients with history of CRN demonstrates altered enzymatic expression of the eicosanoid pathway. Our data indicate a likely gene-based predisposition for early disease development. Furthermore, $\mathrm{PGE}_{2}$ did activate $\mathrm{EP}$ receptors with different affinity including a high affinity EP4 receptor with nanomolar potency to $\mathrm{PGE}_{2}$. Whether this highly sensitive EP4 receptor is tumorigenic and as such could be targeted in CRN management remains to be clarified.

\section{Abbreviations}

AA, arachidonic acid; AKR1B1, aldoketoreductase 1B1; ASA, acetylsalicylic acid; COX-1, cyclooxygenase 1; COX-2, cyclooxygenase 2; Cq, quantification cycle; CRC, colorectal cancer; CRN, colorectal neoplasia; CAMP, cyclic adenosine monophosphate; EP1, prostaglandin E2 receptor subtype 1; EP2, prostaglandin E2 receptor subtype 2; EP3, prostaglandin E2 receptor subtype 3; EP4, prostaglandin E2 receptor subtype 4; GAPDH, glyceraldehyde 3-phosphate dehydrogenase; GW-X, GW627368X; HETE, hydroxyeicosatetraenoic acids; HPETE, hydroperoxydeicosatetraenoic acids; MUAS-chamber, modified Ussing air suction chamber; NSAID, non-steroid anti-inflammatory drug; PTGDS, prostaglandin D2 synthase; $\mathrm{PGE}_{2}$, prostaglandin E2; PTGIS, prostaglandin-I2 synthase; qPCR, quantitative real-time polymerase chain reaction; and SCC, short circuit current. 


\section{Declarations}

\section{Ethics approval and consent to participate}

The study protocol was approved by the Scientific Ethical Committee of Copenhagen (H-3-2013-107) and the Danish Data Protection Agency (BBH-2013-024, I-Suite no: 02342). The study was conducted in accordance with the Helsinki declaration. All participating patients gave written informed consent.

\section{Authors' contributions}

URF was the principal investigator, took part in every aspect of this study and was major contributor in the writing of the manuscript. SKH was a major contributor in performing analyses of functional data and contributed in writing the manuscript. MABH contributed in generating functional data. TAJ contributed as an expert in performing and analyzing the expressional data. NB contributed as an expert in the functional part of the study, its study design, in data analysis and contributed in writing the manuscript. $\mathrm{MBH}$ served as the supervisor of the project and contributed in writing the manuscript. All authors read and approved the manuscript.

\section{Availability of data and materials}

The datasets used and/or analysed during the current study are available from the corresponding author on reasonable request.

\section{Acknowledgements}

We thank the staff at endoscopy unit of Digestive Disease Center at Bispebjerg Hospital for general support. A special thanks goes to Ono Pharmaceutical Co., Ltd. (Osaka, Japan) for providing us with ONO-DI004 and ONO-AE1-259 compounds.

\section{Funding}

This work was kindly supported by grants from Harboefonden (jr.no. 17368), Anita og Tage Therkelsen Fond (jr.no. 100039), Else og Mogens Wedell-Wedellsborg Fond (jr.no. 15-18-1), Trigon Fonden, AndersenIsted Fonden (jr.no 2017-04) and C.C. Klestrup og hustru Henriette Klestrups Mindelegat (jr.no. 10761). TAJ was funded by Lundbeckfonden (R323-2018-3674).

\section{Competing interests}

Mark Berner-Hansen is also a present employee of Zealand Pharma, Denmark. The present work was not related to this affiliation. All authors declare no competing interests.

\section{Consent for publication}

Not applicable. 


\section{References}

1. Bray F, Ferlay J, Soerjomataram I, Siegel RL, Torre LA, Jemal A. Global Cancer Statistics 2018: Globocan Estimates of Incidence and Mortality Worldwide for 36 Cancers in 185 Countries. CA: a cancer journal for clinicians. 2018;68(6):394-424.

2. Fearon ER, Vogelstein B. A Genetic Model for Colorectal Tumorigenesis. Cell. 1990;61(5):759-67.

3. Wang D, DuBois RN. An Inflammatory Mediator, Prostaglandin E2, in Colorectal Cancer. Cancer journal (Sudbury, Mass). 2013;19(6):502-10.

4. Thun MJ, Namboodiri MM, Heath CW, Jr. Aspirin Use and Reduced Risk of Fatal Colon Cancer. The New England journal of medicine. 1991;325(23):1593-6.

5. Thun MJ, Jacobs EJ, Patrono C. The Role of Aspirin in Cancer Prevention. Nature reviews Clinical oncology. 2012;9(5):259-67.

6. Eberhart CE, Coffey RJ, Radhika A, Giardiello FM, Ferrenbach S, DuBois RN. Up-Regulation of Cyclooxygenase 2 Gene Expression in Human Colorectal Adenomas and Adenocarcinomas. Gastroenterology. 1994;107(4):1183-8.

7. Drew DA, Cao Y, Chan AT. Aspirin and Colorectal Cancer: The Promise of Precision Chemoprevention. Nat Rev Cancer. 2016;16(3):173-86.

8. Wang D, Dubois RN. Prostaglandins and Cancer. Gut. 2006;55(1):115-22.

9. Watanabe K, Kawamori T, Nakatsugi S, Ohta T, Ohuchida S, Yamamoto H, et al. Role of the Prostaglandin E Receptor Subtype Ep1 in Colon Carcinogenesis. Cancer research. 1999;59(20):50936.

10. Sonoshita M, Takaku K, Sasaki N, Sugimoto Y, Ushikubi F, Narumiya S, et al. Acceleration of Intestinal Polyposis through Prostaglandin Receptor Ep2 in Apc(Delta 716) Knockout Mice. Nature medicine. 2001;7(9):1048-51.

11. Mutoh M, Watanabe K, Kitamura T, Shoji Y, Takahashi M, Kawamori T, et al. Involvement of Prostaglandin E Receptor Subtype Ep(4) in Colon Carcinogenesis. Cancer research. 2002;62(1):28-32.

12. Fujino H. The Roles of Ep4 Prostanoid Receptors in Cancer Malignancy Signaling. Biological \& pharmaceutical bulletin. 2016;39(2):149-55.

13. Karpisheh V, Joshi N, Zekiy AO, Beyzai B, Hojjat-Farsangi M, Namdar A, et al. Ep4 Receptor as a Novel Promising Therapeutic Target in Colon Cancer. Pathology, research and practice. 2020;216(12):153247.

14. Wang D, Dubois RN. Eicosanoids and Cancer. Nat Rev Cancer. 2010;10(3):181-93.

15. Cathcart MC, Reynolds JV, O'Byrne KJ, Pidgeon GP. The Role of Prostacyclin Synthase and Thromboxane Synthase Signaling in the Development and Progression of Cancer. Biochimica et biophysica acta. 2010;1805(2):153-66.

16. Pidgeon GP, Lysaght J, Krishnamoorthy S, Reynolds JV, O'Byrne K, Nie D, et al. Lipoxygenase Metabolism: Roles in Tumor Progression and Survival. Cancer metastasis reviews. 2007;26(3-4):50324. 
17. Shureiqi I, Chen D, Day RS, Zuo X, Hochman FL, Ross WA, et al. Profiling Lipoxygenase Metabolism in Specific Steps of Colorectal Tumorigenesis. Cancer prevention research (Philadelphia, $\mathrm{Pa}$ ). 2010;3(7):829-38.

18. Michaud A, Lacroix-Pépin N, Pelletier M, Veilleux A, Noël S, Bouchard C, et al. Prostaglandin (Pg) F2 Alpha Synthesis in Human Subcutaneous and Omental Adipose Tissue: Modulation by Inflammatory Cytokines and Role of the Human Aldose Reductase Akr1b1. PloS one. 2014;9(3):1-10 e90861.

19. Larsen R, Mertz-Nielsen A, Hansen MB, Poulsen SS, Bindslev N. Novel Modified Ussing Chamber for the Study of Absorption and Secretion in Human Endoscopic Biopsies. Acta physiologica Scandinavica. 2001;173(2):213-22.

20. Johnson G, Nour AA, Nolan T, Huggett J, Bustin S. Minimum Information Necessary for Quantitative Real-Time Pcr Experiments. Methods in molecular biology (Clifton, NJ). 2014;1160:5-17.

21. Vandesompele J, De Preter K, Pattyn F, Poppe B, Van Roy N, De Paepe A, et al. Accurate Normalization of Real-Time Quantitative Rt-Pcr Data by Geometric Averaging of Multiple Internal Control Genes. Genome Biol. 2002;3(7):RESEARCH0034.

22. Sugimoto Y, Narumiya S. Prostaglandin E Receptors. The Journal of biological chemistry. 2007;282(16):11613-7.

23. Billot X, Chateauneuf A, Chauret N, Denis D, Greig G, Mathieu MC, et al. Discovery of a Potent and Selective Agonist of the Prostaglandin Ep4 Receptor. Bioorganic \& medicinal chemistry letters. 2003;13(6):1129-32.

24. Kjærgaard S, Damm MMB, Chang J, Riis LB, Rasmussen HB, Hytting-Andreasen R, et al. Altered Structural Expression and Enzymatic Activity Parameters in Quiescent Ulcerative Colitis: Are These Potential Normalization Criteria? International journal of molecular sciences. 2020;21(5).

25. Fairbrother SE, Smith JE, Borman RA, Cox HM. Ep4 Receptors Mediate Prostaglandin E2, Tumour Necrosis Factor Alpha and Interleukin 1 beta-Induced Ion Secretion in Human and Mouse Colon Mucosa. European journal of pharmacology. 2012;694(1-3):89-97.

26. Kaltoft N, Tilotta MC, Witte AB, Osbak PS, Poulsen SS, Bindslev N, et al. Prostaglandin E2-Induced Colonic Secretion in Patients with and without Colorectal Neoplasia. BMC Gastroenterol. 2010;10:9.

27. Hong DS, Parikh A, Shapiro GI, Varga A, Naing A, Meric-Bernstam F, et al. First-in-Human Phase I Study of Immunomodulatory E7046, an Antagonist of Pge2-Receptor E-Type 4 (Ep4), in Patients with Advanced Cancers. Journal for immunotherapy of cancer. 2020;8(1).

28. Ching MM, Reader J, Fulton AM. Eicosanoids in Cancer: Prostaglandin E2 Receptor 4 in Cancer Therapeutics and Immunotherapy. Frontiers in pharmacology. 2020;11:819.

29. Roulis M, Kaklamanos A, Schernthanner M, Bielecki P, Zhao J, Kaffe E, et al. Paracrine Orchestration of Intestinal Tumorigenesis by a Mesenchymal Niche. Nature. 2020;580(7804):524-9.

30. Wang D, DuBois RN. Fibroblasts Fuel Intestinal Tumorigenesis. Cell research. 2020;30(8):635-6.

31. Petersen $\mathrm{CH}$, Mahmood B, Badsted C, Dahlby T, Rasmussen HB, Hansen MB, et al. Possible Predisposition for Colorectal Carcinogenesis Due to Altered Gene Expressions in Normal Appearing Mucosa from Patients with Colorectal Neoplasia. BMC Cancer. 2019;19(1):643. 
32. Gustafsson A, Hansson E, Kressner U, Nordgren S, Andersson M, Wang W, et al. Ep1-4 Subtype, Cox and Ppar Gamma Receptor Expression in Colorectal Cancer in Prediction of Disease-Specific Mortality. International journal of cancer. 2007;121(2):232-40.

33. Chell SD, Witherden IR, Dobson RR, Moorghen M, Herman AA, Qualtrough D, et al. Increased Ep4 Receptor Expression in Colorectal Cancer Progression Promotes Cell Growth and Anchorage Independence. Cancer research. 2006;66(6):3106-13.

34. Rigas B, Goldman IS, Levine L. Altered Eicosanoid Levels in Human Colon Cancer. The Journal of laboratory and clinical medicine. 1993;122(5):518-23.

35. Lichao S, Liang P, Chunguang G, Fang L, Zhihua Y, Yuliang R. Overexpression of Ptgis Could Predict Liver Metastasis and Is Correlated with Poor Prognosis in Colon Cancer Patients. Pathology oncology research : POR. 2012;18(3):563-9.

36. Melstrom LG, Bentrem DJ, Salabat MR, Kennedy TJ, Ding XZ, Strouch M, et al. Overexpression of 5Lipoxygenase in Colon Polyps and Cancer and the Effect of 5-Lox Inhibitors in Vitro and in a Murine Model. Clinical cancer research : an official journal of the American Association for Cancer Research. 2008;14(20):6525-30.

37. Tuncer S, Banerjee S. Eicosanoid Pathway in Colorectal Cancer: Recent Updates. World journal of gastroenterology. 2015;21(41):11748-66.

38. Bindslev N. Drug-Acceptor Interactions: Modeling Theoretical Tools to Test and Evaluate Experimental Equilibrium Effects, Pp. 33-57. 1st ed. London, England: Taylor \& Francis Group; 2008. $428 \mathrm{p}$.

\section{Figures}




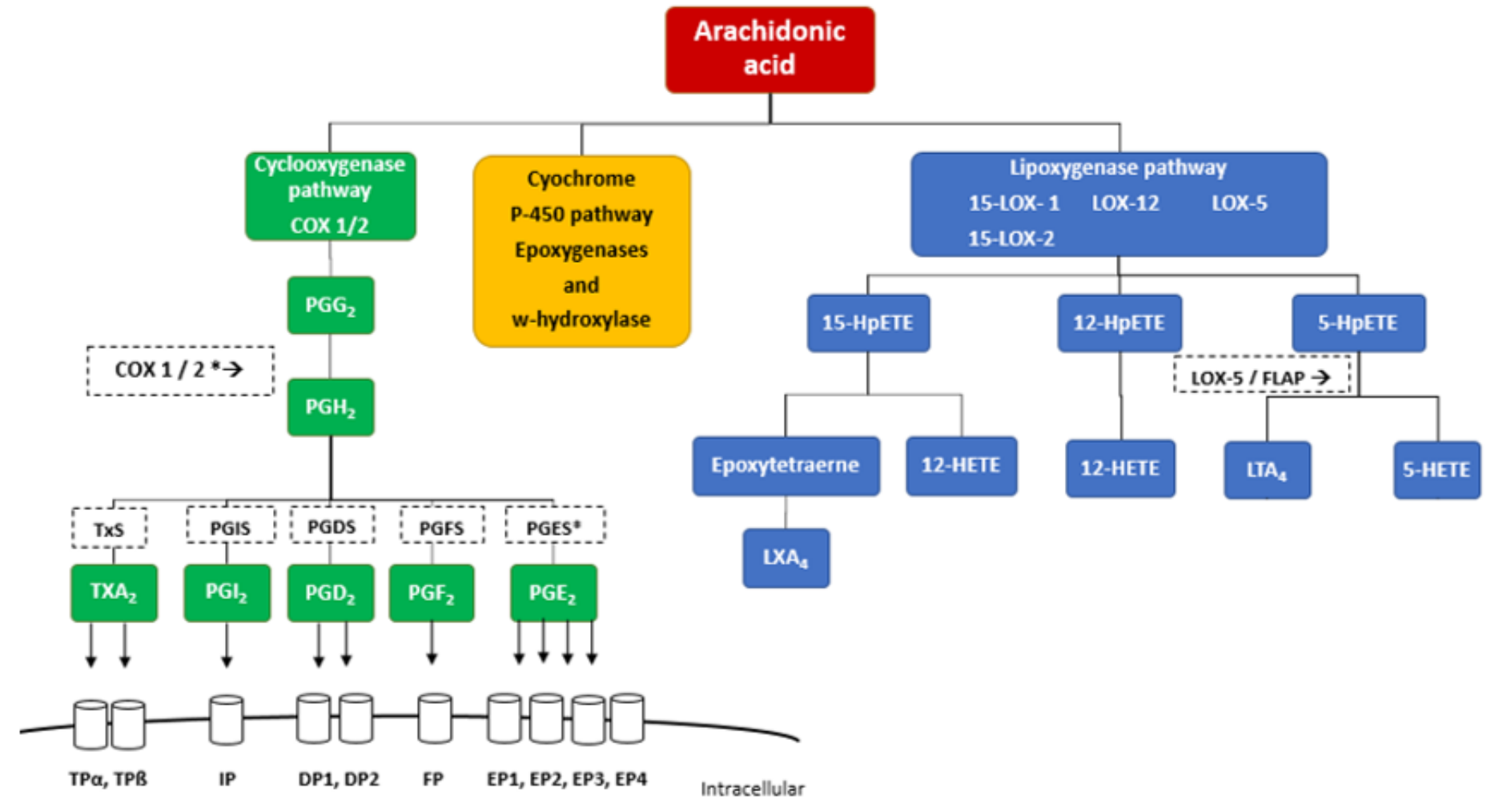

Figure 1

Model of the metabolization of arachidonic acid (AA). AA is metabolized by 3 different groups of enzymes: cyclooxygenases (COX), lipoxygenases (LOX) and epoxygenases (cyto-chrome P450). The COX pathway consists of 2 isozymes: COX-1 and COX-2. Both iso-zymes metabolize AA into PGG2 and then into PGH2, which is further converted to the pros-taglandins (PGs) PGD2, PGE2, PGF2a, PGI2 and thromboxane A2, (TXA2) by their respective synthases (3). Each product binds to its specific membrane receptor. The CYP-450 pathway converts AA by epoxygenases and $\omega$-hydroxylase into other downstream products not shown. The LOX pathway consists of 3 main enzymes termed 5-LOX, 12-LOX and 15- LOX (isozymes 15-LOX-1 and 15-LOX-2). They metabolize AA into hydroperoxydeico-satetraenoic acids (HPETEs), which are further reduced to hydroxyeicosatetraenoic acids (HETEs). The 5-LOX enzyme differs by also metabolizing 5-HPETE into leukotriene A4 by means of 5-lipoxygenase-activating protein (FLAP). * Enzymes already investigated in our laboratories, data published. 
PGE2 Stimulation

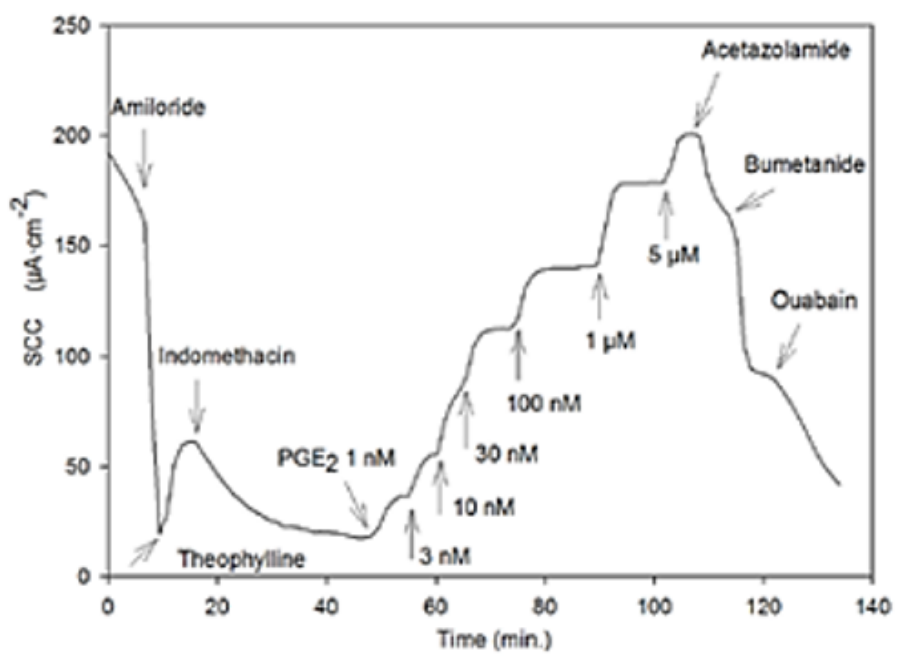

EP4 Agonist Stimulation

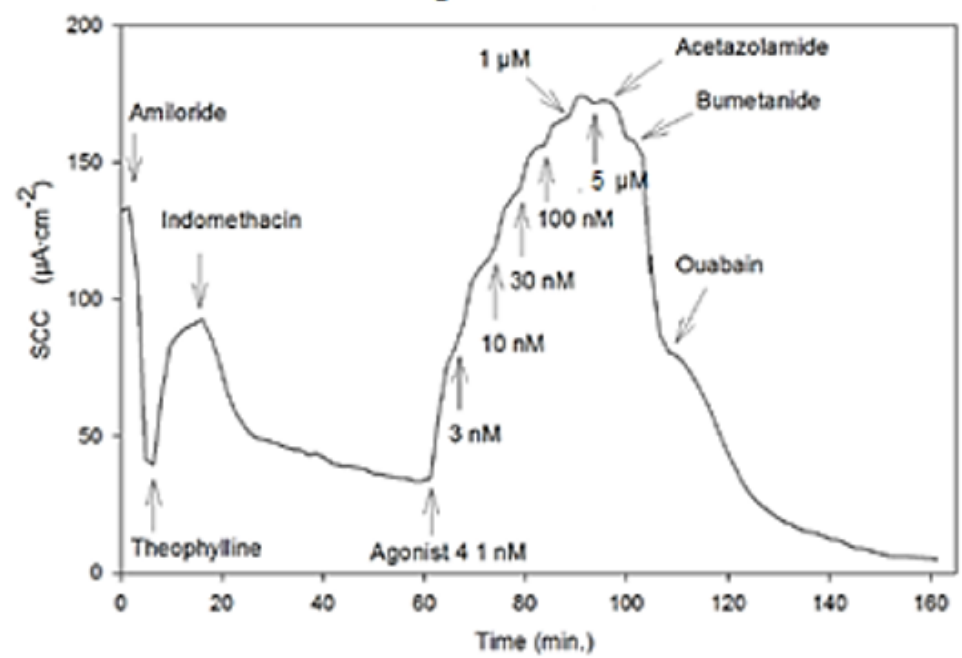

Figure 2

Examples of functional MUAS-chamber experiments. Short-circuit current (SCC, $\mu A \cdot c m \otimes 2)$ measurements from normal appearing human colonic mucosa biopsies in 2 patients with $\mathrm{CRN}$, showing concentration response analysis of prostaglandin E2 (PGE2) stimulation (left) and a EP4 agonist, TCS 2510 (right). Biopsies were exposed initially to amiloride (sodium absorp-tion inhibitor, $20 \mu \mathrm{M}$ ), then theophylline (nonspecific phosphodiesterase inhibitor, $400 \mu \mathrm{M}$ ), then indomethacin (non-specific COX inhibitor, $13 \mu \mathrm{M}$ ) followed by either PGE2 or EP4 ag-onist in increasing concentrations ( $1 \mathrm{nM}-5 \mu \mathrm{M})$, and ultimately acetazolamide (carbonic an-hydrase inhibitor, $250 \mu \mathrm{M}$ ), bumetanide (Na-K-Cl-cotransporter inhibitor, 25 $\mu \mathrm{M})$ and ouaba-in ( $\mathrm{Na}+/ \mathrm{K}+-\mathrm{ATP}$ ase inhibitor, $200 \mu \mathrm{M}$ ). 


\section{$\mathrm{PGE}_{2}$ and EP4 agonist}

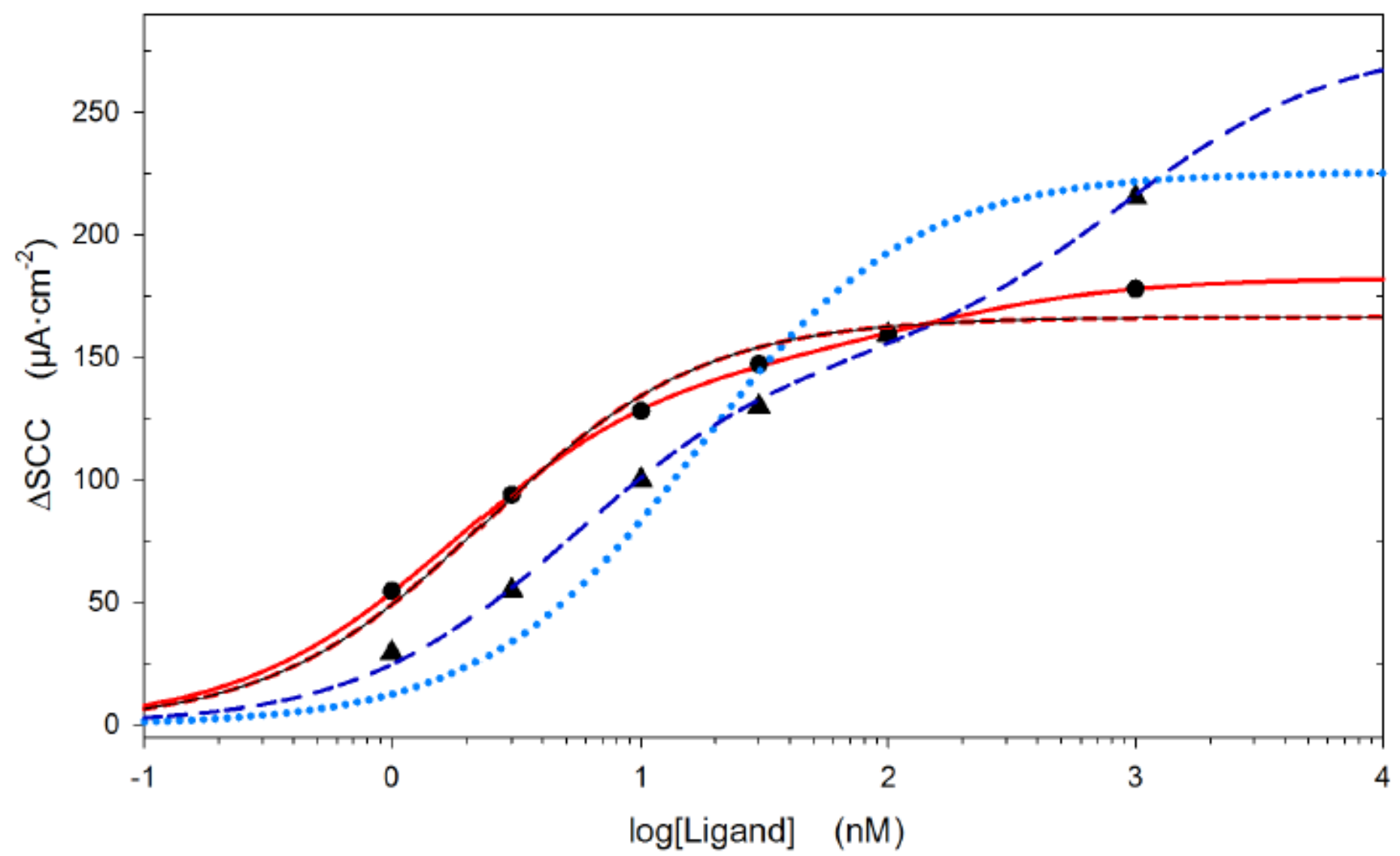

Figure 3

Dose-response curves of PGE2 and EP4 agonist, TCS 2510, experiments. X-axis: ligand con-centrations scaled logarithmically. Y-axis: changes in SCC. Triangles (black) indicate increas-es in SCC as a response to increasing PGE2 concentrations. Large dots (black) show increases in SCC as a response to increasing EP4 agonist concentrations. Dotted and long dotted lines (in blue colors) resemble single (srm) and two receptor model (trm) fitting for PGE2 respec-tively. The unbroken and the medium dotted lines (in red colors) show trm and srm respec-tively for EP4 agonist. The trm fits data points more closely. 


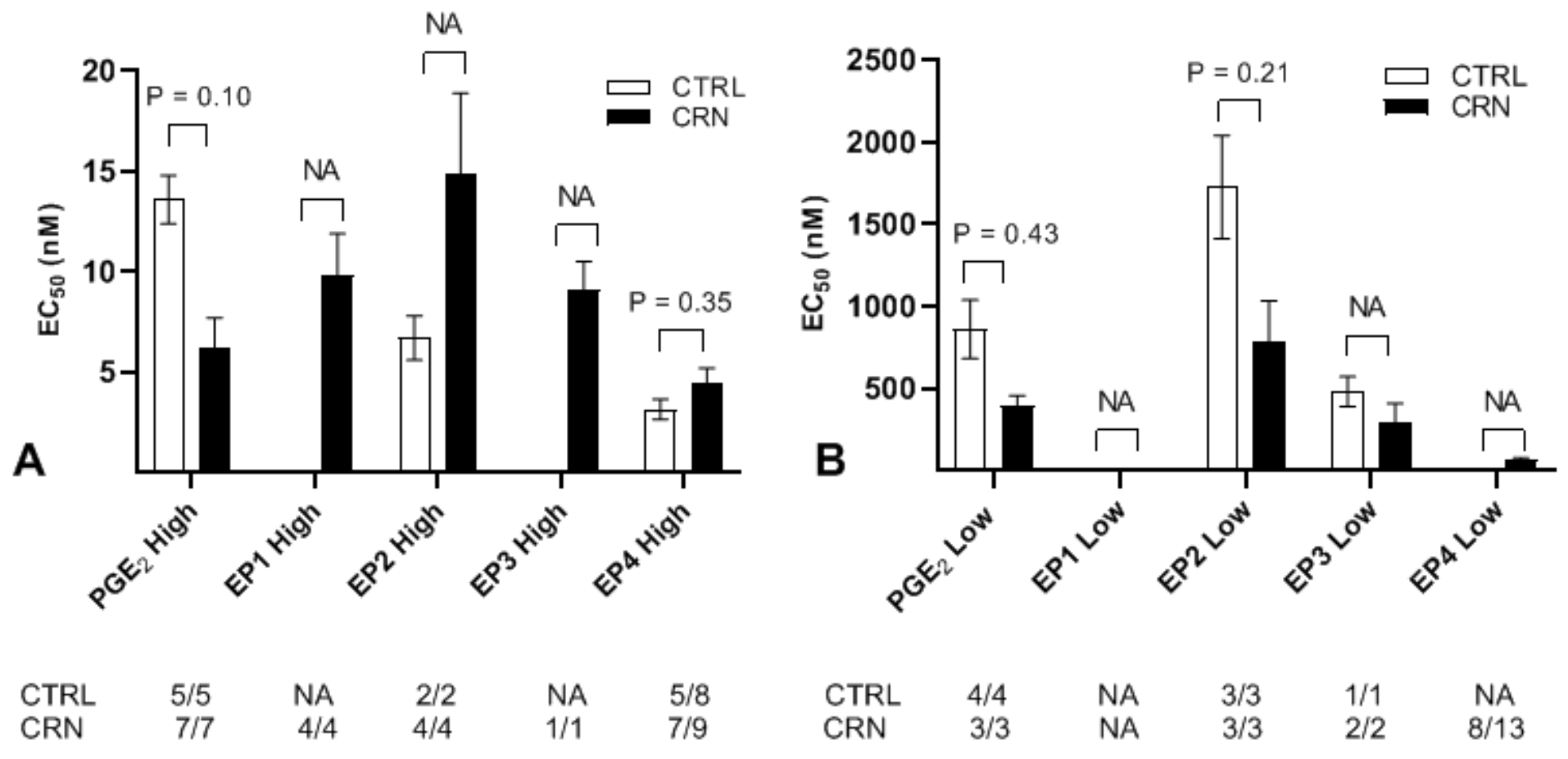

Figure 4

Calculated mean EC50 values of high (A) and low (B) affinity receptors following PGE2 and EP receptor agonists stimulation using two receptor model equations (trm). Numbers under the graph show $N / n, N=$ number of patients, $n=$ number of biopsies, $N A=$ not applicable due to too few $N / n$. Data are presented as means \pm SEM.

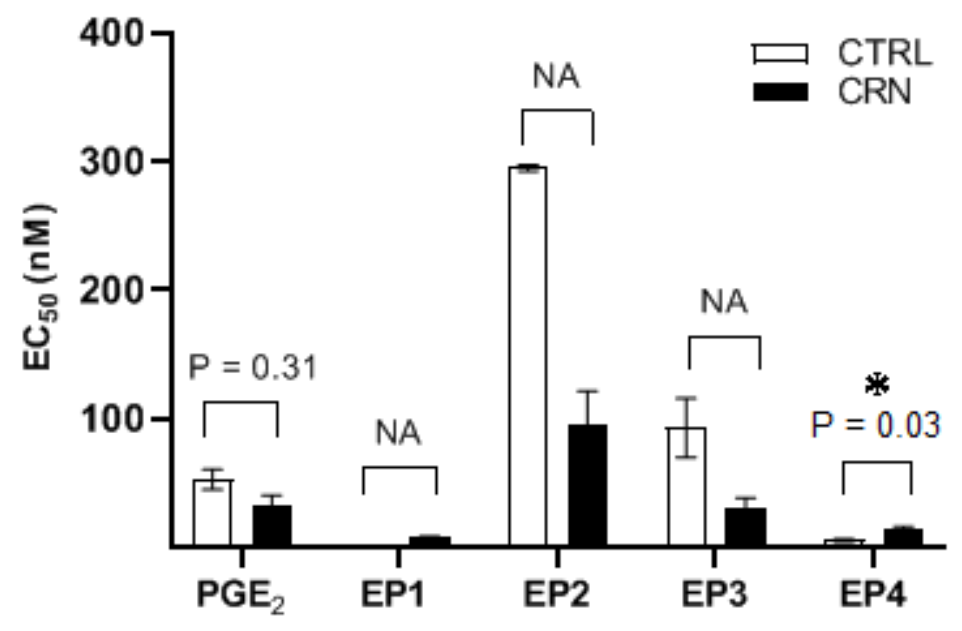

$\begin{array}{llllll}\text { CTRL } & 7 / 7 & \text { NA } & 1 / 1 & 2 / 2 & 7 / 13 \\ \text { CRN } & 9 / 9 & 6 / 7 & 3 / 5 & 3 / 4 & 8 / 15\end{array}$

Figure 5 
Calculated mean EC50 values of PGE2 and EP receptor agonists using single receptor model (srm) equations. Numbers under the graph show $\mathrm{N} / \mathrm{n}, \mathrm{N}=$ number of patients, $\mathrm{n}=$ number of biopsies, $\mathrm{NA}=$ not applicable due to too few N/n. Data are presented as means \pm SEM. ${ }^{*} p<0.05$.

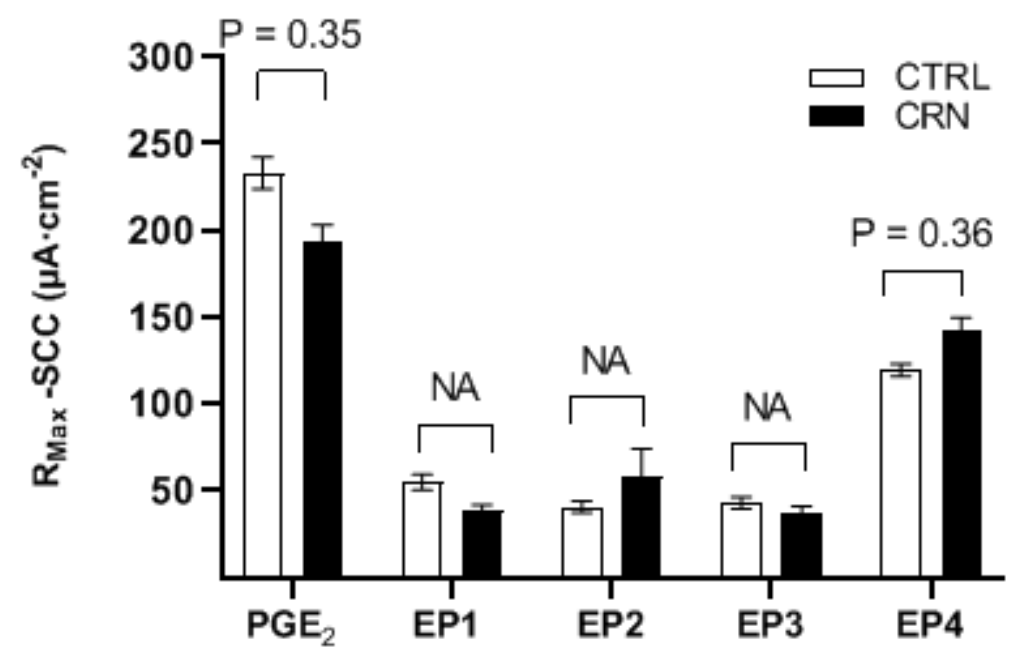

$\begin{array}{lccccc}\text { CTRL } & 8 / 8 & 2 / 3 & 2 / 2 & 2 / 2 & 7 / 12 \\ \text { CRN } & 10 / 10 & 10 / 15 & 10 / 13 & 5 / 8 & 8 / 16\end{array}$

\section{Figure 6}

Calculated mean RMax values displayed as $\mu \mathrm{A} \cdot \mathrm{cm}-2$ from single receptor models upon biopsy stimulation with PGE2 or a selective EP receptor subtype agonist. Numbers under the graph show $\mathrm{N} / \mathrm{n}, \mathrm{N}$ = number of patients, $\mathrm{n}=$ number of biopsies, $\mathrm{NA}=$ not applicable due to too few $\mathrm{N} / \mathrm{n}$. Data are presented as means \pm SEM.

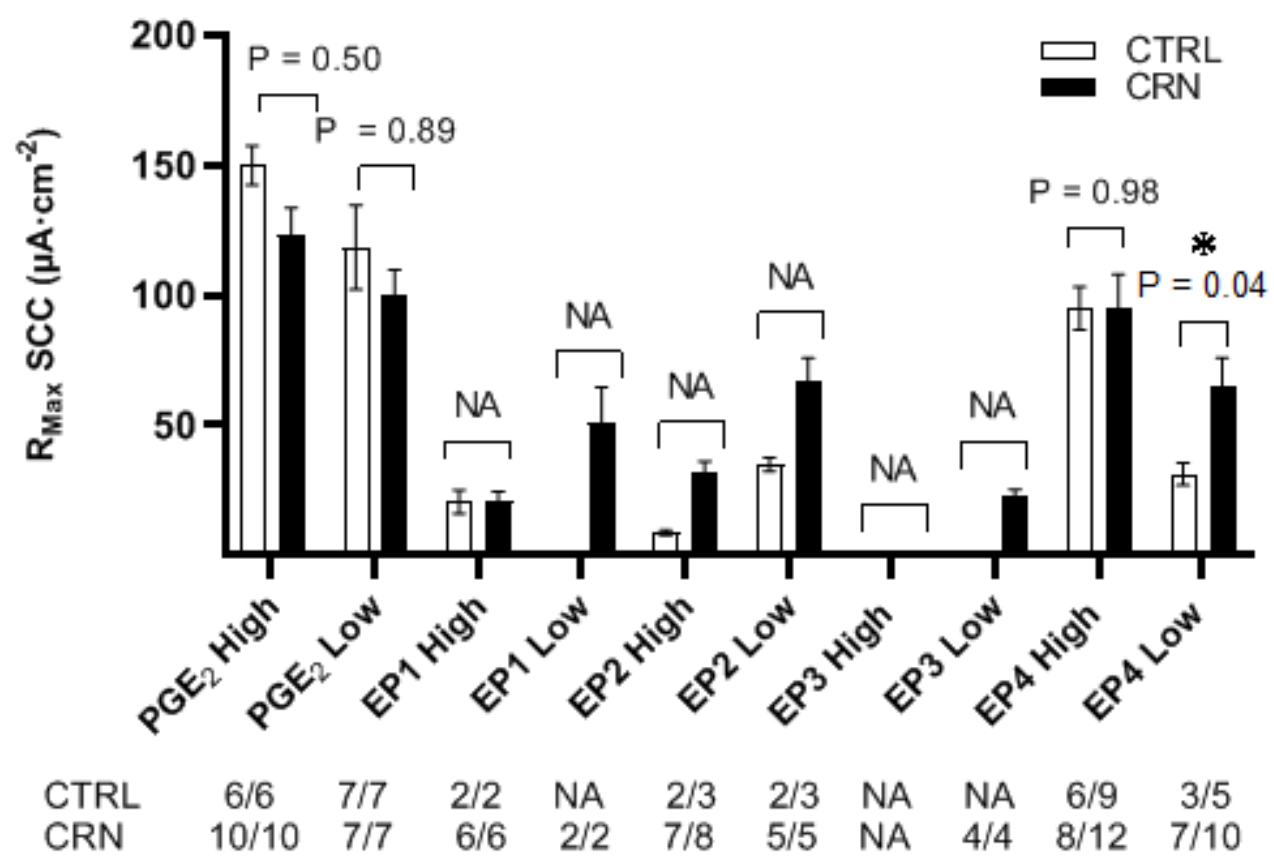




\section{Figure 7}

Calculated mean RMax values displayed as $\mu \mathrm{A} \cdot \mathrm{cm}-2$ from two receptor models upon biopsy stimulation with PGE2 or a selective EP receptor agonist. Numbers under the graph show $N / n, N=$ number of patients, $\mathrm{n}=$ number of biopsies, $N A=$ not applicable due to too few $N / n$. Data are presented as means $\pm S E M .{ }^{*} p$ $<0.05$.

\section{$\mathrm{PGE}_{2}$ and $\mathrm{GW}-\mathrm{X}$}

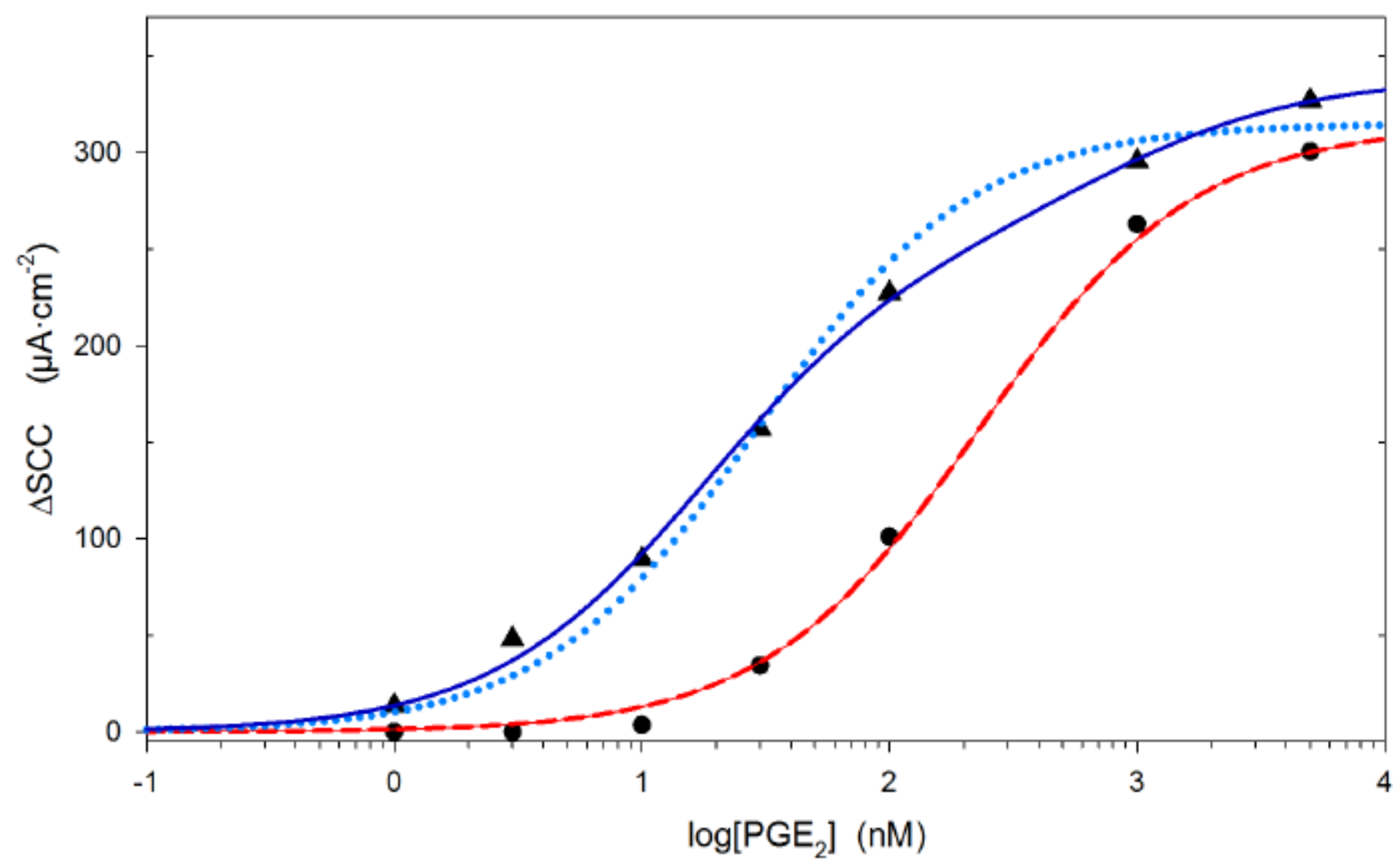

\section{Figure 8}

Dose-response curves of PGE2 stimulation with and without EP4 antagonist GW627368X (GW-X). X-axis: PGE2 concentrations scaled logarithmically. Y-axis: changes in SCC. Trian-gles (black) show increases in SCC as a response to PGE2 doses without the addition of GW-X. Big dots (black) show increases in SCC in the presence of EP4 antagonist GW-X fol-lowed by PGE2 stimulation. The small dotted and the unbroken line (blue colors) resemble single (srm) and two receptor model (trm) fitting. Long dotted line (red) show srm for exper-iments with GW-X, trm could not be calculated. 

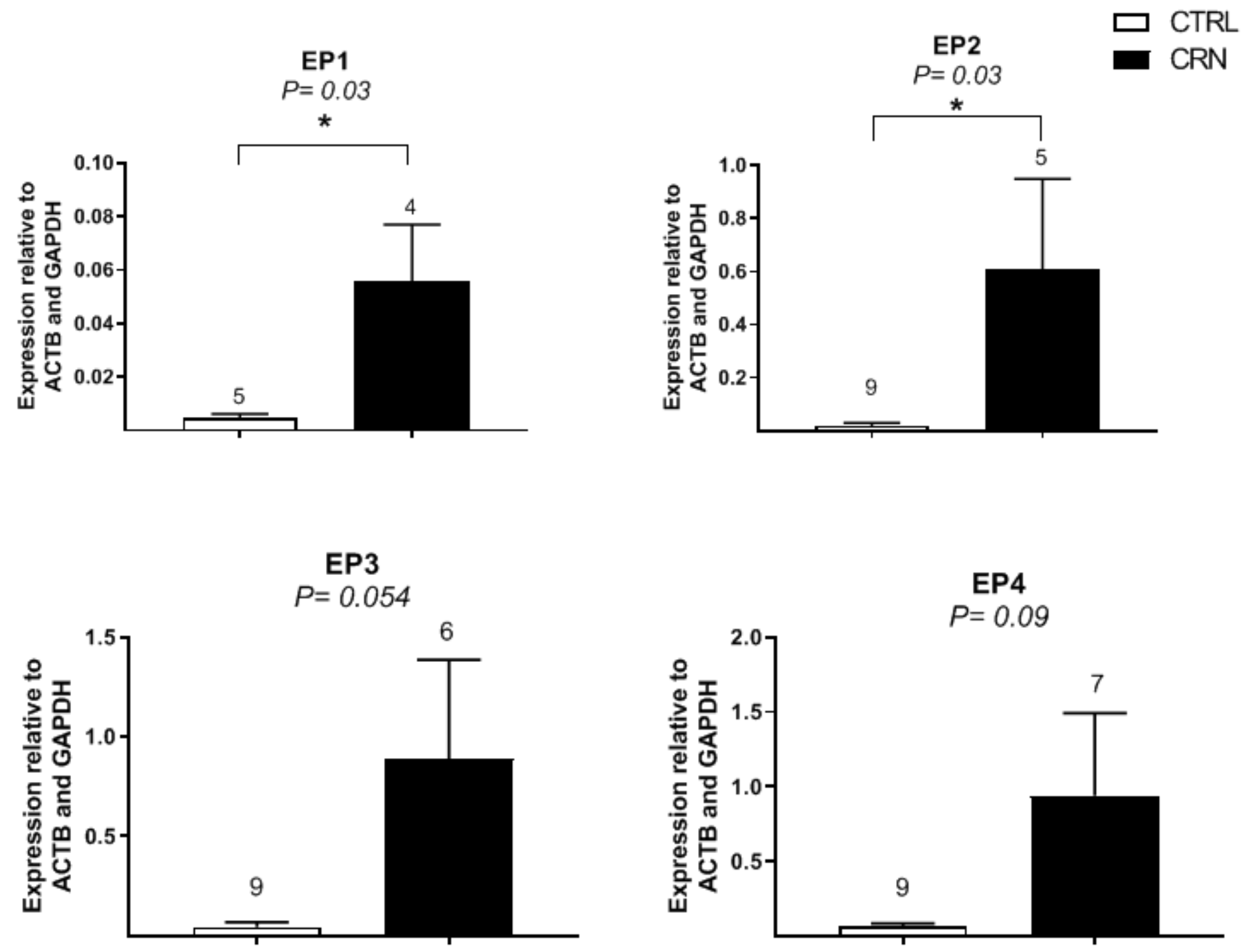

Figure 9

Expression levels of EP receptors. Expression of EP1 and EP2 are significantly higher in CRN patients. Expression levels are relative to $ß$-actin and GAPDH. Data are presented as means $\pm S E M$. ${ }^{*} p<0.05$. 

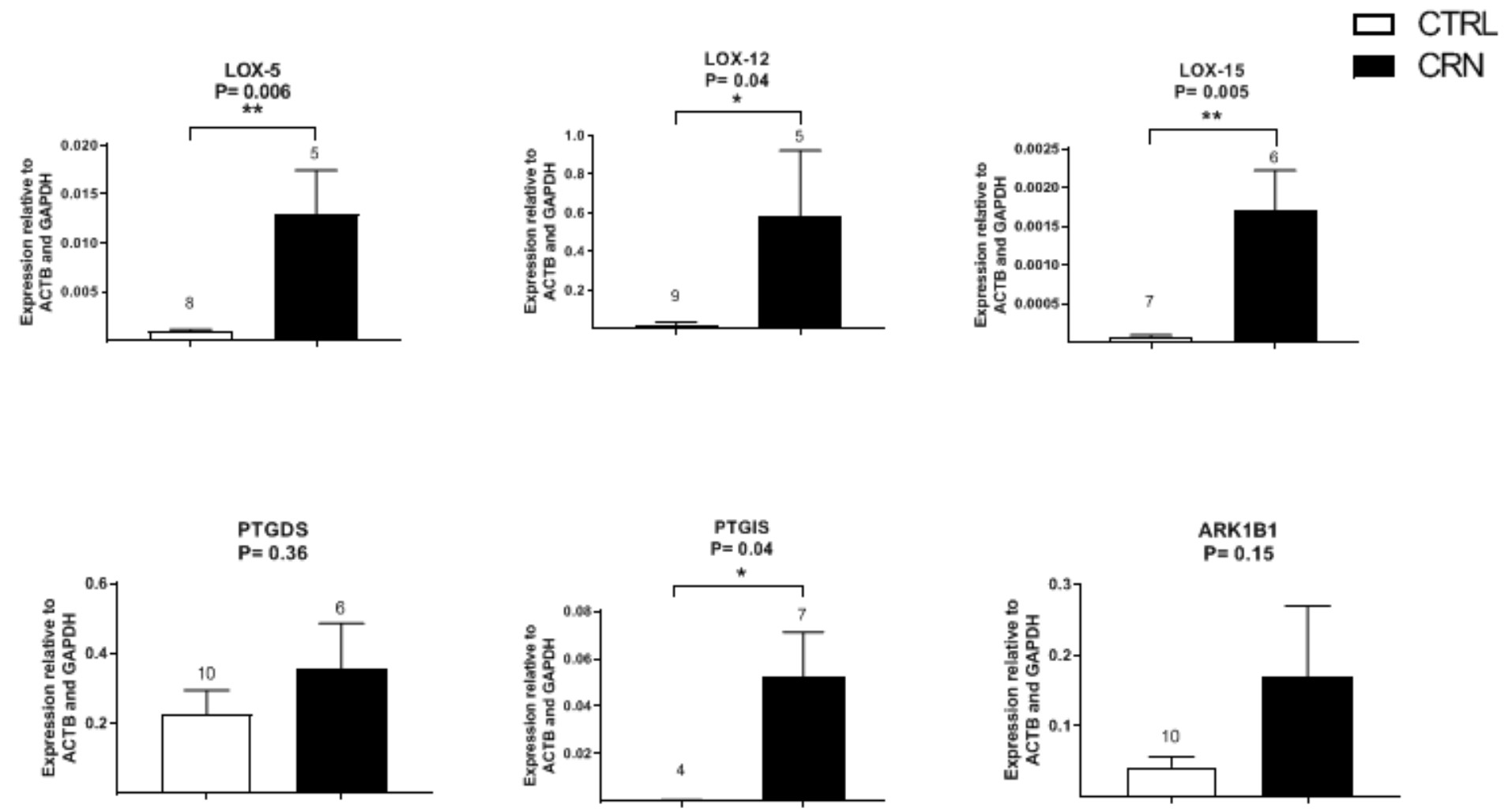

Figure 10

Expression levels of lipoxygenases and prostaglandin synthetases. Expression of 5-LOX, 12-LOX, 15-LOX as well as PTGIS are significantly higher in CRN patients. Expression levels are relative to $ß$-actin and GAPDH. Data are presented as means \pm SEM. ${ }^{*} p<0.05$ and $* * p<0.01$.

\section{Supplementary Files}

This is a list of supplementary files associated with this preprint. Click to download.

- Additionalfile1U.Feddersen.docx

- Additionalfile2U.Feddersen.docx 